\title{
MODERNISATION OF ART EDUCATION OF A FUTURE TEACHER UNDER CONDITIONS OF GLOBALISATION
}

\author{
Olena Malytska \\ Ph.D., Associate Professor, Berdyansk State Pedagogical University, Ukraine \\ e-mail: sokolska116@gmail.com,orcid.org/0000-0001-6296-5957
}

\section{Summary}

The article addresses the reflection of the processes of globalisation in contemporary art and their influence on the content and technologies of art education of a future teacher. The emphasis was placed on the fact that even under conditions of globalisation, artistic culture cannot be transformed on the basis of unification because it leads to the loss of ethnocultural values of a certain nation and the destruction of their cultural genotype. It was determined that the only direction of the transformation of modern art is integration technologies. The classification of integration methods in modern art practices is offered according to the following forms: mutual influence of cultural concepts on a territorial basis; the synergy of traditions and innovations; the combination of modern technologies into a conglomerate that preserves the characteristics of an art object; innovative synthesis of traditional arts on a group or type basis. Attention was focused on the fact that globalisation processes, that take place in the modern world, affect the content and determine the technologies of art education. It was established that among the forms of artistic integration of contemporary arts, that were proposed by the author, such as the synergy of traditions and innovations as well as the synthesis of traditional arts on a group or type basis are mainly introduced in the art education of a future teacher.

Keywords: cultural globalisation, concept of artistic integration, synthesis of arts, integration technologies in art, art education of a future teacher, methodological approaches to art education of a future teacher, competence approach in art education.

DOI: https://doi.org/10.23856/4213

\section{Introduction}

The modern world is characterised as a society of the globalisation period, which causes the emergence of new phenomena in all aspects of its existence. Culture and art are one of the largest spheres of influence of the existing globalisation processes.

However, if such social spheres as economics, politics, religion are globalised on the basis of unification, then in the artistic culture this process is based primarily on the principles of integration. One can observe the synthesis and interaction of not only different spheres of artistic culture but also their integration with purely scientific processes and other "non-artistic" phenomena. Conglomerates that result from such interactions cannot be attributed to purely art objects.

These transformations of artistic culture in postmodern society under the influence of globalisation processes cause changes in art education too. Modern artistic competences involve a comprehensive cognition of the surrounding reality and holistic acquisition of social, cultural, moral and psychological components of art, which contribute to the emergence of new phenomena as creative manifestations of a teacher. Navigation through the modern sociocultural phenomena requires awareness of various types of artistic practice both 
traditional and synthetic. That is, the synthesis of arts is a key characteristic of modern art education of a future teacher. It is the purpose of this article to determine the system of methodological approaches to art education of a future teacher in the context of the modern concept of synthesis of arts.

This article proposes to consider the reproduction of globalisation processes in the content and technologies of art education. They are caused by such aspects as the synthesis of different groups and types of arts and the combination of different art technologies, which leads to the appearance of a new art product that cannot be attributed to any of the traditional groups or forms of art (such as land art and green art, etc.). The integral processes in the sphere of art on a territorial basis or those that are caused by a combination of technologies, are more characteristic of professional art and are practically not represented in the art education of a future teacher.

\section{The influence of globalisation processes on modern art}

The globalisation of culture in the modern world is a phenomenon in which differentiation and integration, cooperation and conflicts, partial and general are not mutually exclusive, but are predictable trends in the existence of a society. Thus, the transformations caused by cultural globalisation are perceived not only as positive shifts in social processes but also as extremely negative processes. Among the aspects of cultural globalisation that get a negative colouring, some researchers identify the loss of national identity of different nations, their ethnocultural peculiarities, the destruction of cultural genotype and replacement of traditional for a particular society values up to the complete absorption by the other civilization. Moreover, they even see in them the risk of losing by a person his/her own freedom in his/her cultural space. That is, such modern processes are of dialectical character: "If antiglobalists ask whether a person will be free, if it is necessary to be "just like everyone else", then the globalists ask whether a person will be free if you cannot be "just like everyone else" (Holubynska, 2017). This struggle between globalists and antiglobalists is considered to be the spirit of the times in all spheres of modern society.

From a philosophical point of view, the globalisation of culture is a process of integration of separate national cultures into a single world culture (Danilian, Dzoban, 2017). That is, it is, first of all, integration, convergence, the interaction of certain elements of a certain system. This interpretation characterises any aspect of globalisation and is its generalizing definition in all spheres of society. The globalisation of world culture can be considered in a slightly different aspect. Globalisation causes flourishing of artistic diversity not only due to such common factors as the enrichment of some cultures by the others, access to various information, development of technologies but also due to specific aspects of artistic synthesis, such as: the renaissance of customs, values and their modern rethinking and merging of arts of different groups and types into a single concept. Given the specifics of art, we can identify a number of aspects of this process that are characteristic of only this area of human activity.

Thus, in art, the manifestations of globalisation processes can be described in several forms: interaction on a territorial basis, the synergy of traditions and innovations, the combination of technologies and the synthesis of on a group or type basis.

Therefore, globalisation in art on a territorial basis is defined as a synthesis of features of Eastern and Western arts (Pryharina, 2020), a unification of national cultures (Holubynska, 2017), merging of national cultures into a single global culture (Chernyshova, 2019), westernization with the standards of British-American society, which are influential factors in the transformation of value orientations of other peoples (Tetiushkina, 2010). Ethnoculture is considered to be 
one of the means of counteracting the negative globalisation processes and the threat of ethnic deculturalization (Oksiutovych, 2014).

The synergy of traditional aspects of art and innovative cultural forms involves the restoration of traditional art centres, the emergence of unique art practices and creation of a new art product based on them that is stylistically close to authentic traditions. In Ukraine, such art activities are realised, for example, by synthesizing traditional stylistic trends in folk decorative arts and their innovative transforming, using the concepts of the Ukrainian conceptual picture of the world and their synthesising in modern artistic interpretations, using home painting traditions in modern art practices (Studenets, 2019), landscape art as a form, through which modern cultural groups gain possibilities to create and maintain their identity (Fesenko, 2019), etc. However, there is a position that the excessive desire to solve the artistic problems of the present by way of focusing on the values and heritage of the past is unpromising (Oksiutovych, 2014).

An important factor in the processes of artistic integration is a rapid development of technology. It is the development of technology and access to information that allows to integrate various spheres of human activity and art, which has caused the emergence of the phenomena that cannot be considered only art objects. Such phenomena include the works of science art the field of contemporary art at the junction of artistic and scientific, creative and technological or bio art, the creators of which use the achievements of biotechnologies and work with living matter. In most recent studies, the situation of the interaction of different types of arts as well as art and "non-art" has been defined as intermediality, and the intermedia strategy - as the implementation of a similar situation in creative activity (Tymashkov, 2012: 35).

Such shifts in the field of artistic culture, of course, have their impact on the processes of modern art education.

\section{Reproduction of the globalisation of artistic processes in art education}

Usually, the globalisation of certain modern systems is determined from the standpoint of unification and integration. However, such perspectives of globalisation transformations do not reproduce the specifics of the arts. Integration is interpreted in scientific literature as a state of the connectedness of separate differentiated parts and functions of the system into a unitary whole, as well as a process leading to such a state (Shashenkova, 2010). The other interpretation of integration defines it as an ordering process and structuring of the internal relations of the unity of common values (Levichev, 2013). In general, unification is a process that is antagonistic to a creative one.

Modern orientation towards globalisation predictably requires new strategies in education. Pursuant to the globalisation paradigm that forms a picture of the modern world, we can consider the concept of art synthesis a leading one for the formation of a future teacher's ability to convey topical social meanings and values of the modern culture to a child. The renewal of the methodological basis in the context of the synthesis of arts is one of the factors contributing to the solution of the problems of modern art education of future educators.

In pedagogical research, synthesis is considered at the level of integration processes, and some researchers identify it with integration. However, synthesis involves a combination of various phenomena, things, qualities and opposites into integrity, in which their specific contradictions and opposites are smoothed out or disappear altogether. Synthesis is the highest stage in the development of a phenomenon, which combines the progressive elements of the former stages of development (Yefremova, 2000). That is, synthesis is always a new product. Synthesis is interpreted as an organic combination and relationship of its various types 
in a complete work of art based on a single ideological plan (Dictionary of the Ukrainian language, 1970-1980:186). This approach to the interpretation of the definition of "synthesis of arts" determines the methodological fundamentals of art education, which are understood in the context of the values relevant to a particular sociocultural and economic situation as changes in an education system are always caused by changes in society.

A methodological approach is a scientifically substantiated basis for the study of an object of the pedagogical science, determines the logic and stages of its study, interpretation of empirical data, allows to determine the strategy of assessment and correction of the phenomenon under study. The use of a certain, scientifically substantiated system of methodological approaches improves the quality of training of a future primary education specialist and reproduces information about the effectiveness of this process for the purpose of timely adjustment of its strategy and tactics.

The problems of formation of professional mastery of future pedagogues are covered in the research of L. Vashchenko, O. Ovcharuk, L. Karpova, O. Pometun, I. Zymnia, L. Khoruzha and others. Various aspects of the introduction of an innovative system of methodological approaches in an educational process of higher educational institutions are reflected in the works of such scholars as M. Hrynova, O. Ionova, O. Oleksiuk, V. Palamarchuk, H. Shevchenko, N. Shyian, H. Selevko, L. Semenovska.

The use of innovative approaches to the professional training of a future teacher is paid attention to in the works of V. Bespalko, B. Hershunskyi, V. Lozova, H. Padalko, I. Osadchenko, B. Skinner, V. Tymenko and others.

Modern approaches to the organisation of an educational process at higher educational institutions are studied in the works of N. Popovych (competence approach), Ye. Bondarevska, V. Slobodchykov, I. Yakymanska (person-oriented approach), V. Davydov, I. Iliasov, N. Talyzina (activity approach), I. Isaiev, H. Haisyna, Ye. Shyianova (culturological approach).

Improving the process of forming artistic orientations of a teacher, which meet modern integration requirements, causes the problem of forming competences that are necessary for this. Therefore, N. Popovych believes that such competences are divided into two groups: “...a group of subject competences that accumulates special, methodological, procedural, informational, technological, multicultural and comparative competences and a group of acme competences that embraces acme, synergetic, prognostic, reflexive, value, world view, intellectual and pedagogical competences of a teacher..." (Popovych, 2017: 18). According to the scholar, the formation of such competences stimulates future specialists' self-organisation, self-development, self-improvement and self-realisation in the field of contemporary art.

The following appropriate competences can be identified as those that will allow future teachers to acquire modern art as a synthetic phenomenon:

- the readiness to use knowledge of the concepts of modern spiritual culture of humankind when completing educational and professional tasks;

- the ability to analyse modern artistic phenomena and use this knowledge when completing specific educational tasks at a general secondary educational institution;

- the readiness to use individual creative abilities to complete creative tasks in an educational process at a general secondary educational institution;

- the readiness for one's own creative activity (Malytska, 2020).

Among the important innovations that ensure the formation of the above competences of a future teacher there are:

- acquisition of methods and techniques of artistic activity;

- acquisition of the technology for teaching skills and techniques of artistic activity; 
- the ability to manage artistic and creative activities of children (Malynska, 2010).

Given the above, the following methodological approaches to the organisation of an educational process at pedagogical higher educational institutions can be identified as relevant: culturological, creative, activity, person-oriented and axiological ones. Despite the specifics and differences, they are united by the commonality of components. Each of these approaches characterises within its framework the goals of education, the content and peculiarities of the organisation of an educational process and the assessment of educational outcomes through a set of general principles. The commonality of these approaches is also determined by the general functions that they perform in an educational process at a pedagogical higher educational institution and ensure the success of an organisation and provision of art education of future teachers. These include: philosophical, informative, adaptive, normative, cognitive, praxeological, communicative and transformational functions.

Sociocultural content of pedagogical education is a topical direction of domestic education policy. The new educational standards focus on the development of a creative component in the structure of a child's personality in the context of modern artistic culture as one of the conditions for a child's harmonious development.

In modern research, a culturological approach is defined as a priority in an educational environment at a higher educational institution, as in pedagogical science there is a transition to the paradigm of education from the standpoint of culture. V. Slastonin believes that the culturological approach directs an educational process towards the level of practical "humanity studies." (Slastonin, 2005: 34).

In the modern process of transition of an educational paradigm "... to the person-oriented technologies of pedagogical education aimed at developing a subject character of an educator, his/her professional and pedagogical culture and creative style of pedagogical activity, the higher education acts as an institute of expanded reproduction and development of culture" (Haisyna, 2002: 3).

N. Krylova considers the culturological approach as a set of techniques “...that ensure analysis of any sphere of human life and activity in the light of system-forming culturological concepts such as culture, cultural patterns, norms and values, a way of life and lifestyle, person and society, cultural activity and interests" (Krylova, 2000: 65). The above- mentioned approach contributes to the process of formation of a teacher as a person of high culture, capable of effective art-oriented training of junior pupils. It is based on the unity of social and culturological aspects and a comprehensive social and culturological analysis of modern phenomena.

A culturological approach ensures the acquisition of specific peculiarities of modern art by an individual, in particular, its synthetic manifestations. This is possible because a student becomes familiar with the achievements of artistic culture from a globalisation viewpoint, that is, the synthesized artistic phenomena of different societies are analysed by him/her on the basis of general concepts. It should be noted that the lack of understanding of both historical and contemporary artistic phenomena makes it impossible to effectively solve many pressing pedagogical problems. The adoption of a culturological approach into the system of training of specialists in pedagogical higher educational institutions involves the creation of conditions for each student to acquire artistic and aesthetic experience of humankind and creative self-realisation on this basis in any types of artistic activity.

A culturological approach in art education of future teachers allows to optimise the pedagogical potential of art in the process of forming their professional qualities. The directions of its implementation in the educational environment at a pedagogical higher educational institution are: 
- the formation of value orientations of students in the process of the emotional experience of art;

- the development of the capacity for the sensory and figurative acquisition of environmental phenomena;

- acquisition of sociocultural functions in creative activity;

- the formation of notions of the phenomena of modern artistic culture for creative self-expression and self-determination of a person.

Thus, art education at a pedagogical higher educational institution in the context of a culturological approach is focused on a person of a future teacher as a synthesis of universal and professional cultures.

The above-mentioned approach is the basis for the adoption of a creative approach into an educational process of a pedagogical higher educational institution as it creates possibilities to use the formed creative potential of a student, that was developed in the field of art, in other areas of human activity. The avoidance of reproductive actions and the transition to an individual way of their implementation in any activity can be considered the result of the effective implementation of a creative approach.

There are four stages of development of a person's creativity: imitation (copying), creative imitation, imitative creativity and true creativity (creation). If the first two forms of creativity can be attributed to educational activities, then the others are aspects of a creative one. Thus, a creative approach in an educational process at a higher educational institution contributes to the shift of emphasis from educational activities to transformational ones.

An activity approach is aimed at attracting a higher education student to both artistic and pedagogical as well as one's own artistic and creative activities. In the context of this approach, a student is a subject of activity, communication and any social relations who consciously determines their specificity and direction to achieve certain goals. This approach allows you to adjust the ratio of reproductive and creative aspects of cognitive processes and to adjust the student's self-regulation.

A person-oriented approach in the art education of a future teacher involves the transition to subject relations and contributes to the awareness of the aspects of the process of profession acquisition and conscious direction of one's own activity to the development of artistic and pedagogical competence. This approach requires a teacher to create conditions that take into account not only interests, needs and possibilities but the level of the creative potential of a student too.

An axiological approach defines a harmonious creative person as the highest value of society and the primary objective of its possible transformations. In the process of conscious acquisition of the principles, methods and ways of artistic activity, there takes place the acquisition by a subject of the value system and its transformation into certain personal formations. Therefore, according to this approach, the process of forming a future specialist is determined by the system of value notions of a future teacher of artistic and pedagogical as well as artistic and creative activities. Thus, the effectiveness of the influence on a person of a future teacher is caused by the presence of a certain system of value orientations and their significance in the structure of life meanings of a person.

In modern research, a competence approach is interpreted as dominant in determining the potential directions of innovative development of the system of artistic training of a teacher. According to N. Popovych, to create an effective system of artistic training of a teacher, the implementation of a competence approach offers the strongest possibilities (Popovych, 2015). 


\section{Conclusions}

Globalisation processes, which are observed in all spheres of modern society, lead to the globalisation of artistic culture, which, in turn, causes transformations in art education.

In art, we can identify two opposite directions of this phenomenon. On the one hand, it is the focus on unification, on the other hand - strengthening of the ethnocultural factor that is recognised by antiglobalists as the only condition for preserving national peculiarities, cultural genotype of different nations and preserving traditional values of a certain society.

However, globalisation in contemporary art can be considered as a purely artistic process without the other non-artistic components that integrates only the phenomena of artistic culture. This position will make it possible to avoid the negative aspects of «classical» globalisation in artistic activity, among which one of the dominant is the «westernisation» of artistic culture.

Modern rethinking and transformation of traditional values as well as the creation of a new art concept by means of synthesis of different groups and types of arts can be attributed to purely artistic integration processes.

The concept of art synthesis is not innovative. However, the rethinking of it in the context of globalisation and modernisation of modern society will solve the fundamental problems of losing the authentic qualities of artistic activity and the inconsistency of art education of a future teacher to modern realities of artistic culture.

The concept of art synthesis should be interpreted as the core of the method of interconnected comprehension of modern processes of individualisation and globalisation of artistic creativity and as a way to find intersystem ties in the context of the development of art education of a modern teacher.

Artistic integration can be successfully implemented in the art education of a future teacher under condition of the introduction of the system of methodological approaches that embodies modern global sociocultural values, allows to transform them into personal values and to realise them as an object in the creative activity of students. Such a system integrates culturological, creative, activity, person-oriented, axiological and competence approaches and performs informative, adaptive, integrative, philosophical, cognitive, praxeological, communicative and transformational functions, which ensures the success of the organisation and provision of art education of future teachers.

\section{References}

Bilodid I. K. (Ed.) (1970-1980) Slovnyk ukrainskoi movy. vol. 9. Kyiv: Naukova dumka. [in Ukrainian]

Chernyshova E. N. (2019) Problemy formirovaniya globalnoj kultury [Problems of formation of a global culture]. Bolshaya Evraziya: Razvitie, bezopasnost, sotrudnichestvo, no. 2-2, pp. 656-658. Retrieved from https://cyberleninka.ru/article/n/problemy-formirovaniya-globalnoy-kultury [in Russian].

Danilian O. H. \& Dzoban O. P. (2017) Hlobalizatsiia kultury: protyrichchia ta tendentsii rozvytku [Cultural globalization: contradictions and trends in development]. Visnyk Natsionalnoho universytetu «Iurydychna akademiia Ukrainy imeni Yaroslava Mudroho», no. 2 (33), pp. 28-41. Retrieved from: https://docplayer.net/71871724-Globalizaciya-kulturi-protirichchya-ta-tendenciyi-rozvitku.html [in Ukrainian]

Efremova T. F. (2000) Novyj slovar russkogo yazyka. Tolkovo-obrazovatelnyj [New dictionary of the Russian language. Explanatory and educational]. Moscow: Rus. yaz. [in Russian]. 
Fesenko G. G. (2019) Miski landshafty i tradytsiina kultura: problema zberezhennia avtentychnosti $v$ umovakh hlobalizatsiinykh protsesiv [urban landscapes and traditional culture: the problem of preserving authenticity in the context of globalization processes]. Tradytsiina kultura $v$ umovakh hlobalizatsii: synerhiia tradytsii ta innovatsii: materialy naukovo-praktychnoi konferentsii (21-22 chervnia). Kharkiv: Drukarnia Madryd. pp. 322-324 [in Ukrainian]

Gaysina G. I. (2002) Kulturologicheskiy podhod v teorii i praktike pedagogicheskogo obrazovaniya [Cultural approach of the theory and practice of teacher education. (Doctoral dissertation). Moskovskij gosudarstvennyj pedagogicheskij universitet. Moscow, Russia. Retrieved from: http://irbis.gnpbu.ru/Aref_2002/Gajsina_G_I_2002.pdf [in Russian]

Golubinskaya A. V. (2017) Diversifikaciya i unifikaciya kultur v globalnom veb-prostranstve [Diversity and unification of cultures in the global web space]. Vek globalizacii, no. 1, pp. 98-105. Retrieved from: https://cyberleninka.ru/article/n/diversifikatsiya-i-unifikatsiya-kultur-v-globalnom-veb-prostranstve [in Russian]

Kryilova N. B. (2000) Kulturolohyia obrazovanyia [Cultural studies of education]. Moscow: Narodnoe obrazovanye. [in Russian]

Levichev O. F. (2013, November). Kategoriya sinteza kak aspekt metanauchnosti sovremennoj pedagogicheskoj mysli [The category of synthesis as an aspect of meta-science of modern pedagogical thought]. Portal nauchno-prakticheskih publikacij. Retrieved from: http://portalnp.ru/ 2013/11/1413 [in Russian]

Malinskaya L. L. (2010) Pedagogicheskie usloviya podgotovki budushih uchitelej izobrazitelnogo iskusstva $k$ rukovodstvu hudozhestvenno-tvorcheskoj deyatelnostyu shkolnikov [Pedagogical conditions for the preparation of future teachers of fine arts to guide the artistic and creative activities of schoolchildren]. (Doctoral dissertation). Bashkirskij gosudarstvennyj pedagogicheskij universitet. Ufa, Russia. Retrieved from: http://www.rusnauka.com/1_NIO_2012/ Pedagogica/2 95883.doc.htm [in Russian]

Malytska $O . \bar{V}$. (2020) Realizatsiia stratehii intermedialnosti v mystetskii osviti maibutnoho vchytelia: metodolohichni pidkhody [Implementation of an intermedial strategy in the art education of a future teachers: methodological approaches]. Aktualni pytannia humanitarnykh nauk: zb. nauk. prats, Drohobytskyi derzhavnyi pedahohichnyi universytet im. Ivana Franka, no. 33, pp. 238-242. Retrieved from: http://dspace.bdpu.org:8080/xmlui/handle/123456789/3296 [in Ukrainian].

Oksyutovich M. O. (2014) Etnokultura v konteksti globalizacijnih procesiv: socialno-filosofskij analiz [Ethnoculture in the context of globalization processes: socio-philosophical analysis]. (Doctoral dissertation). Zhytomyrskyi derzhavnyi universytet im. Ivana Franka. Zhitomir, Ukraine. Retrieved from: http://eprints.zu.edu.ua/10763/1/Oksjutovich.pdf [in Ukrainian].

Popovych N. M. (2015) Teoriia i metodyka formuvannia profesiino osobystisnoho dosvidu vchytelia muzyky v systemi neperervnoi pedahohichnoi osvity [Theory and methodology of formation of professional and personal experience of music teachers in the system of continuing teacher education]. (Doctoral dissertation). Kyivskyi universytet im. Borysa Hrinchenka. Kiev, Ukraine. Retrieved from: https://kubg.edu.ua/images/stories/Departaments/apirantam/ Avtoreferat/D.26.133.06/avtoreferat_popovych.pdf [in Ukrainian].

Prigarina I. A. (2020) Globalizaciya v sovremennom iskusstve: tematicheskie aspekty [Globalization in contemporary art: thematic aspects]. Hudozhestvennaya kultura, no. 3, pp. 106-127. Retrieved from: https://cyberleninka.ru/article/n/globalizatsiya-v-sovremennom-iskusstve-tematicheskie-aspekty [in Russian].

Shashenkova E. A. (2010) Issledovatelskaya deyatelnost [Research activities]. Moscow: Perspektiva. [in Russian] 
Slastonin V. A. (2005) Refleksivnaya kultura i professionalizm uchitelya [Reflexive culture and professionalism of the teacher]. Pedagogicheskoe obrazovanie i nauka, no. 3, pp. 37-42. [in Russian]

Studenets N. V. (2019) Synerhiia tradytsii khatnoho rozpysu v suchasnykh khudozhnikh praktykakh [Synergy of home painting traditions in modern artistic practices]. Tradytsiina kultura $v$ umovakh hlobalizatsii: synerhiia tradytsii ta innovatsii: materialy naukovo-praktychnoi konferentsii (21-22 chervnia 2019). Kharkiv: Drukarnia Madryd. pp. 322-324 [in Ukrainian].

Tetyushkina S. A. (2010) Vesternizaciya kak sociokulturnoe yavlenie [Westernization as a socio-cultural phenomenon]. Socialno-gumanitarnye znaniya, no. 1, pp. 145-154. Retrieved from: https://cyberleninka.ru/article/n/vesternizatsiya-kak-sotsiokulturnoe-yavlenie [in Russian]. Timashkov A. Yu. (2012) "Vse» $i$ «Nichto» : intermedialnaya strategiya tvorchestva K. S. Malevicha ["Everything" and "Nothing" : an intermediate strategy of K. S. Malevich's creativity]. Vestnik Omskogo universiteta, no. 1 (63), pp. 299-304. Retrieved from: https://cyberleninka.ru/ article/n/vsyo-i-nichto-intermedialnaya-strategiyvorchestva-k-s-malevicha [in Russian] 